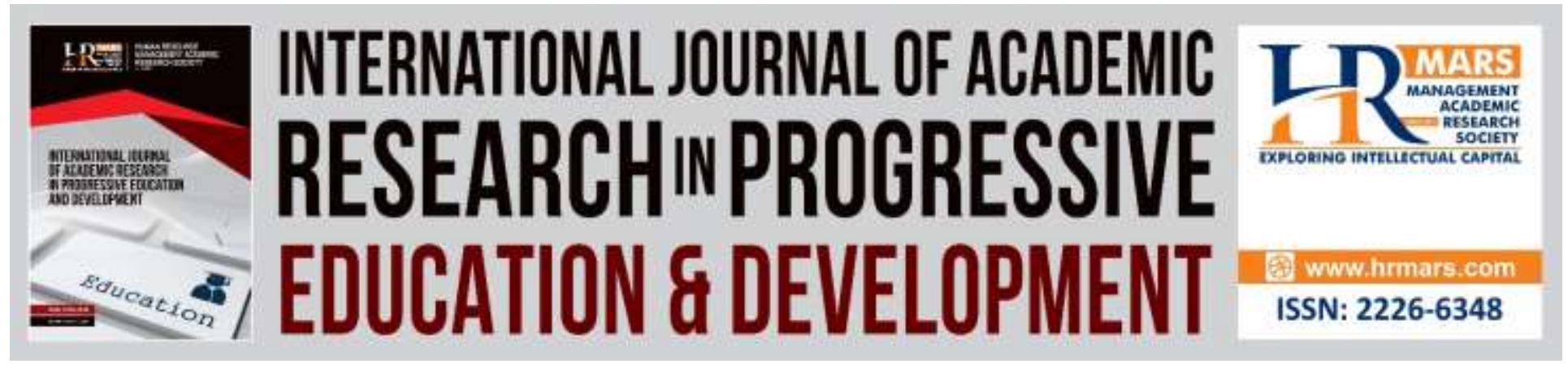

\title{
The Use of Feedback in the Classroom Assessment: A Case Study
}

\section{Senin Khamis, Asri Selamat}

To Link this Article: http://dx.doi.org/10.6007/IJARPED/v8-i3/6426

DOI: $10.6007 /$ IJARPED/v8-i3/6426

Received: 30 July 2019, Revised: 12 August 2019, Accepted: 01 September 2019

Published Online: 22 September, 2019

In-Text Citation: (Khamis \& Selamat, 2019)

To Cite this Article: Khamis, S., \& Selamat, A. (2019). The Use of Feedback in the Classroom Assessment: A Case Study. International Journal of Academic Research in Progressive Education and Development, 8(3), 325334.

Copyright: (C) 2019 The Author(s)

Published by Human Resource Management Academic Research Society (www.hrmars.com)

This article is published under the Creative Commons Attribution (CC BY 4.0) license. Anyone may reproduce, distribute, translate and create derivative works of this article (for both commercial and non-commercial purposes), subject to full attribution to the original publication and authors. The full terms of this license may be seen at: http://creativecommons.org/licences/by/4.0/legalcode

Vol. 8(3) 2019, Pg. 325 - 334

Full Terms \& Conditions of access and use can be found at http://hrmars.com/index.php/pages/detail/publication-ethics 


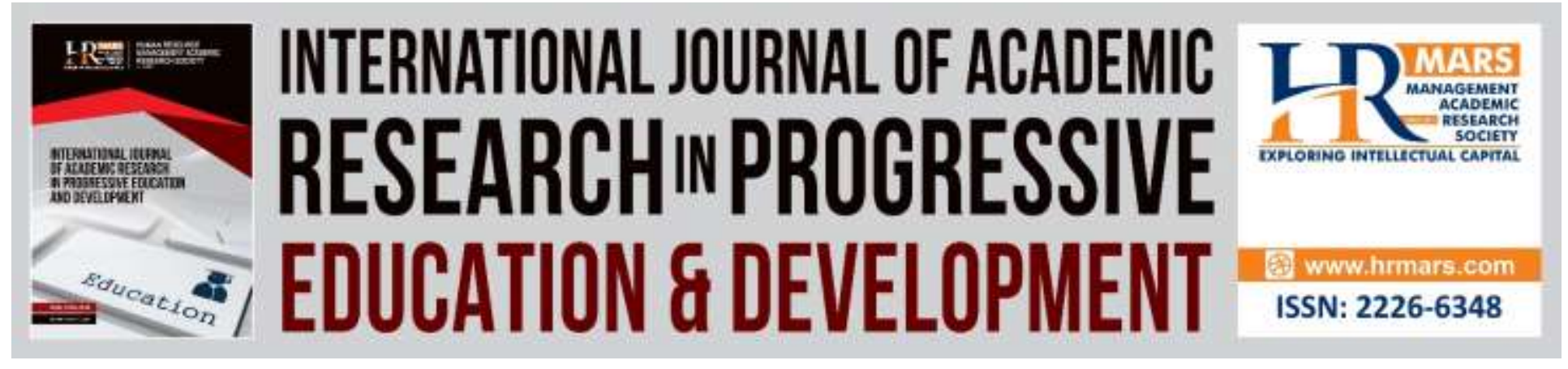

\title{
The Use of Feedback in the Classroom Assessment: A Case Study
}

\author{
Senin Khamis ${ }^{1}$, Asri Selamat Ph.D² \\ ${ }^{1}$ IPG Kampus Perempuan Melayu, Melaka, Malaysia, ${ }^{2}$ Universiti Tun Hussien Onn Malaysia
}

\begin{abstract}
Assessment and feedback are a crucial element in providing pupils' learning performance in the classroom. This study aims to explore the practice of using feedback in classroom assessment among the primary school - Cluster School of Excellence teachers in Malacca. In particular, it provides information on understanding the concept of classroom assessment and evaluates the practice of giving feedback towards pupils' learning outcomes. This qualitative study involved 8 teachers, 4 core subject teachers in Malay, English, Science and Mathematics and 4 teachers involved in the management of assessments namely the Headmaster, Senior Administrative Assistant, School Assessment Coordinator and SIC + who were chosen as the research sample to be interviewed. The findings concerning the understanding of the concept and the function of classroom assessment for primary school Cluster Excellence teachers are very clear. The findings of the practice of giving feedback to pupils' work indicate that the practice is common however the feedback information is very limited in use among teachers.
\end{abstract}

Keywords: Assessment, Classroom Assessment, Feedback, Learning Performance, Learning Outcomes.

\section{Introduction}

A good assessment and evaluation system can harness the potential and talents of the existing pupils. Assessment in education can be a driving force in shaping individuals who are intellectually, physically, spiritually, emotionally, emotionally and highly skilled (Malaysian Examination Board, 2013). This is because assessment is an important part of the teaching and learning process, not only to assess what students are learning but to help teachers identify their teaching methodology. Accordingly, the Ministry of Education Malaysia has taken steps to make classroom assessment a vehicle for measuring student development, progress and mastery of the Content Standards and Learning Standards (CSLS) as stated in the Curriculum and Assessment Standard Document (CASD) of each subject by an ongoing assessment.

Classroom assessment (CA) has become increasingly important in the 21st century education world. According to McMillan (2014), CA has been a powerful influence on learning and has successfully motivates students. CA itself is a process that demonstrates what students really learn, what students really know, helps students to gain in depth understanding and most 
importantly enhances the effectiveness of teacher's teaching. According to Stiggins (2010), it is suggested that teachers need to develop a strong understanding of classroom assessment in order to balance between the assessment for learning and the assessment of learning. Many teachers do not have a clear concept of a classroom assessment whereas its practices play a key role in determining the education quality.

According to the Ministry of Education Malaysia (2018), CA is a continuous process of teaching and learning sessions to obtain information on pupils' development, progress, ability and mastery of the desired curriculum goals. Popham (2013) states in his book "Classroom Assessment: What Teachers Need to Know" explains about the 2 perspectives related to classroom assessment, the traditional view of why teachers implement classroom assessment and the second view is the function of a classroom assessment. The traditional perspectives are regarding the function of classroom assessment as a diagnose to see the pupils' strengths and weaknesses, monitoring progress, grading the pupils and determining teacher's teaching effectiveness. On the other hand, the current perspective has three functions, assessment can influence public perception of educational effectiveness, to evaluate teachers and to explain teacher's teaching effectiveness. Therefore, it is believed that classroom assessment strongly influences the education system that exists today as it reflects the strength of the teacher and the school.

Classroom assessment does not only measure pupils' achievement but assessment is seen as an indicator to see how well the pupil is learning, and their ability to do what teachers expect from the learning outcomes received (Popham, 2013). This statement is supported by Payne (2003) who mentioned that assessment not only focuses on the nature of the pupil but also on what and how the pupil learns.

\section{Problem Statement}

Beginning from 2011, the Primary School Integrated Curriculum (PSIC) has been replaced by the Primary School Curriculum Standard (PSCS). This new modular curriculum has given every student an opportunity to go through their own learning process, fostering a sense of responsibility for their own learning through exploration activities that highlight their potential. Changes in curriculum design have also led to changes in assessment methods. PSCS emphasizes formative assessment aimed at assessing the development of student learning processes. But since the end of 2016, School Assessments have come to be known as Classroom Assessments (CA). The Council maintains all the concepts of School Assessments and involves determining the level of student mastery in each subject (Ministry of Education Malaysia, 2018). Implementing CA in schools will continue to improve the quality of education so that it is more relevant to the current and future challenges. In this process, teachers play an important role in delivering an effective teaching and learning. The level of teacher's concern is crucial to support any change that occurs in the school especially to make large-scale changes (Maskan, 2013).

CA aims to improve pupils learning through formative assessments, namely assessment for learning and assessment as learning. However, CAs can also be used to look at pupils' achievement after a reasonable period of time through a summative assessment (Ministry of Education Malaysia, 2018). As assessment for learning is one of the components of CA, such assessment activities can assist learning by providing information for teachers and pupils. 
Through these activities they can evaluate themselves and their peers, while also enhancing their teaching and learning activities (Black \& Wilson, 2009).

For researchers, good feedback practice features can help assess the assessment practices and can improve self-regulated learning; explaining best practices to facilitate the development of self-assessment in learning, providing high quality information to pupils about their learning; encourage discussion during learning; promotes motivation with positive beliefs and self-esteem, and provides an opportunity to bridge the gap between current and desired performance (Nicol \& Macfarlane-Dick 2006). Beyond this specification, researchers are interested in studying the practice and the use of feedback in classroom assessments implemented by teachers during the teaching and learning process.

\section{Purpose of the Study}

The purpose of this study is to explore the practice of using feedback in classroom assessment during the teaching and learning process. Specifically, the purpose of this study is to fulfill the following objectives:

i. To understand the concept of classroom assessment.

ii. Exploring the practice of using feedback in classroom assessment.

\section{Research Questions}

Based on the above objectives, this study can answer the following questions:

i. How well do primary school teachers understand the concept of classroom assessment?

ii. How far is the practice of using feedback in classroom assessment implemented?

\section{Importance of Study}

The results of this study can provide an overview concerning teachers' understanding of the classroom assessment's concept and the use of feedback during the assessment process for classroom learning. This finding can help stakeholders to execute activities and take action to ensure that the use of feedback is practiced correctly among teachers in the school.

\section{Research Methodology \\ Research Design}

This study was conducted using qualitative methods and conducted as a case study. It was selected based on the desire to develop an in depth understanding and to gain a vivid picture (Yin, 2017) in relation to the understanding of the basic concepts of classroom assessment and the use of feedback during the assessment process for classroom learning. In an effort to make the study phenomenon more meaningful, a study was conducted at one of the Malacca's state primary school "Cluster School of Excellence" (CSE). Selection of the participants were conducted using purposive sampling which was based on the assumption that researcher want to explore, apprehend and discern the use of feedback (Merriam, 2009). A total of 8 teachers who are the 4 core subject teachers in Malay (BM), English (BI), Science (SCE) and Mathematics (MATH) and another 4 teachers who involved in the assessment management namely Headmaster (HM), Senior Administrative Assistant (SAA), School Assessment Coordinator (SAC) and School Improvement Specialist Coach (SISC+) were used as interview samples. 


\section{Instrument of Study}

The study instrument used was a semi-structured interview. In this study, the interview questions were divided into 2 sub-topics related to the concept of CA and the use of feedback implemented by the teachers. In general, interviews are about knowing what is going on in a person's mind (Patton, 2014). This allows the researcher to see from the interviewee's perspective in regards to the understanding of the CA concept and the practice of using feedback in the school.

\section{Data Analysis}

The interview data in this study were analyzed manually through three procedures as described by Miles and Huberman (2015), namely, grouping data, presenting data and verifying data. In detail, the recorded interviews are transcribed. The interview verbs were analyzed to perceive the teachers' understanding of the CA concept as well as the practice of using feedback based on several identified themes. According to Lebar (2012); Ahmed, Isa, Majid, Zin, \& Amin, (2017). It is advisable to the researcher to forthwith the data processing upon the completion of the interview, to entirely understand the phenomenon of the study.

\section{Research Findings}

The findings are presented based on the research questions to explore teachers' understanding of the CA concepts and the practice of using feedback in classroom assessment.

i. How well do primary school teachers understand the concept of classroom assessment?

Based on the discussions and interviews with the respondents, they were very aware of the purpose of assessment in the classroom. They argue that the purpose of assessment is to evaluate the effectiveness of teacher teaching and learning, to assist teachers in assessing learning objectives and to test what students learn throughout their teaching. According to McNergney and McNergney (2007) stated teachers have three major responsibilities in implementing classroom assessment. First; teachers need to know what their students need in their learning; second, teachers must be aware of their students' capabilities and abilities in relation to their learning goals and third, teachers should have various teaching strategies and methods. This phenomenon is portrayed by the interviews result with the teachers as follows:

From what I can understand, assessments are ongoing process. We always assess students from the beginning of the year to the end of the year, we monitor his development, from incompetent to competent. [R7T1-10/9 (BM)]

To me, it means that the function of assessment is to evaluate the effectiveness of teaching and learning. In addition, assessment can also help the teacher assess whether or not his or her learning objectives have been achieved. [R4T1-10 / 9 (BI)]

The function is that we want to know the objective of achieving it ... to know how much the student has mastered. [R1T1-10/9 (MATH)] 
Vol. 8, No. 3, 2019, E-ISSN: 2226-6348 ㄷ 2019 HRMARS

The assessment's function is to test what a pupil learns throughout the teaching through teachers' observation, pupils' work, so we can see the pupil's ability. [R3T1-10/9 (SCE)]

From what I see as an administrator ... assessment takes place throughout the course of teaching and learning, which can contribute to improvements. [R6T1-11/10 (HM)]

The findings of this study are also supported by the findings of Nizam et al., (2014) where respondents of her study stated that the purpose of the assessment was to provide feedback on student progress, identify student shortcomings and weaknesses and make decisions concerning further actions, what the teachers and pupils need to do. Acar-Erdol and Yildizli (2018); Ahmed, Umrani, Qureshi, \& Samad (2018). explained that classroom assessment requires a new approach by focusing on pupils' feedback, providing peer assessment and group assessment, in addition to individual and teacher assessment which focus on the learning process. It should be done by engaging the pupils in all assessment processes and most importantly, the teacher can practice this assessment in the teaching and learning process. In conclusion, this finding proves that these primary school teachers have a high understanding of the concept of assessment in education. According to Abdullah et al., (2015) and Sulaiman et al., (2016), when teachers have the knowledge and skills to implement classroom assessments, they can also directly improve the teaching and learning process in the classroom.

ii. How far is the practice of using feedback in classroom assessment implemented?

The analysis of teacher-related interviews of using feedback in the CA revealed that the practice is common among the CSE teachers. According to Reeves (2001) feedback on pupils' learning outcomes is important to provide pupils with immediate, relevant and useful information whilst Shute (2008) described feedback as helpful to pupils in changing their thinking or behavior to improve their learning. This is described in the interview as follows:

I just wrote it as 'good' ..... there was also a tidy writing. However, I also wrote in short ... not in details ... I just commented ... 'good' ... 'complete it' [R1T1-10 / 9 (MATH)]

I like to use stars, sticker, remarks good in their exercise books ... and this makes the students proud ... they will show them to their friends ....that's all that I did. No lengthy comments. [R4T1$10 / 9(\mathrm{BI})]$

Good or continue the effort ... For proficient pupils, I write good, for the weak I will write try again, please complete the work and so on. I award star for the Standard 1 pupil while I provide written comments for my Standard 5 and 6 pupils. [R5T1-11/10 (SAA)]

I remark 'good'...my comments are just that. If there is a mistake, I wrote do correction. [R6T1-11/10 (HM)] 
Vol. 8, No. 3, 2019, E-ISSN: 2226-6348 @ 2019 HRMARS

Normally ... if it's good we will write 'good'... if there is a mistake ... we'll call him but there's no point to expose about it to the whole class ... we call him individually ... if he writes nicely ... we award it with a star... that's it. [R3T1-10/9 (SCE)]

As for me ... I would rather comment and usually if there is a chance, I will call the student ... For example, for year 4 pupils, if the task is incomplete, I will write in the book. On the other hand, for year 1, if the writing is untidy, I'll call them because it will be difficult for them to read the comments. [R7T1-10/9 (BM)]

I always see teachers just write well.. keep trying ... get your job done ... which is usually a teacher. [R8T1-26/10 (SISC+)]

There are ...... examples I write to me ...I write again, fix the completed writing with the date and the day once ... tell the students to correct it ....that is. [R2T1-24/9 (SAC)]

The findings of this study are in line with the findings of Ali and Jamaluddin (2007) and Suah et al., (2007) on Malaysian secondary and primary school teachers in Malaysia. Similarly, Bramwell-Lalor \& Rainford (2016); Ahmed, Majid, \& Zin (2016). findings on biological teachers in Jamaica found that $95.0 \%$ of respondents strongly agreed that comments and written feedback should be written on student work. But most of the feedback that these CSE teachers usually use is simply to write the words "good", "get your work done", "keep up the effort", "paste stickers" and other simple statements. This statement is also corroborated by the findings of Ravikumar (2015) study which shows that teachers simply comment and reinforce in the student handbook by writing words such as 'good', 'satisfactory' or grade such as ' $A$ ' and so on. This statement is supported by Henry (2002) explaining that students are very interested in comments that ask them to correct assignments and strongly dislike comments that criticize their efforts and achievements.

In conclusion, the practice of using feedback in the CA for Malacca primary school teachers shows that practice is common and frequently used during Teaching and Learning. However, teachers at CSE are very likely to use grades and grades as feedback in their assessment practices. While providing student feedback on the strengths and weaknesses of students has a very low tendency in practice.

\section{Discussion and Conclusion}

The findings of this study show that although the concept and function of assessment are understood by the teachers of the CSE, the practice of using feedback among the teachers is still writing basic comments. The feedback expressed by the teachers indicated that the comments provided were only qualified to provide feedback in the student activity book. In particular, such feedback should be viewed from many aspects not only as a correction for student error but as one of the continuous assessment mechanisms in the classroom (Gamlem \& Smith, 2013). According to Stiggins, Arter, Chappius, \& Chappius, (2007), the feedback itself gives students the opportunity to make self-assessments and their results can be shared with peers. Cauley and McMillan (2010) further emphasize that the practice of using feedback is to give students the 
opportunity to express themselves in learning activities that indirectly enhance the student's intrinsic motivation.

This indicates that writing feedback for primary school CSE teachers has not yet achieved the true features of the feedback function as noted by Wilson (2010) that there are three key features related to feedback, first; the feedback should be from the pupil to the teacher where the teacher can determine the actual level of student achievement, the second is the feedback from the teacher to the pupil where the feedback can help the student to understand or adding in-depth and third-party knowledge to students where through student feedback can help one another. In conclusion, teacher practices provide feedback and comments as a tool to help teachers implement CAs and provide students with opportunities to use meta-cognitive strategies such as self-planning, self-monitoring and self-reflection.

\section{References}

Ahmed, U., Majid, A. H. A., \& Zin, M. L. M. (2016). HR Moderating HR: Critical link between Developmental HR Practices and work engagement in a Moderated Model. Management Review: An International Journal, 11(2), 4-22.

Ahmed, U., Umrani, W. A., Qureshi, M. A., \& Samad, A. (2018). Examining the links between teachers support, academic efficacy, academic resilience, and student engagement in Bahrain. International Journal of Advanced and Applied Sciences, 5(9), 39-46.

Ahmed, U., Isa, N. M., Majid, A. H. A., Zin, M. L. M., \& Amin, B. M. (2017). Towards understanding work engagement: can HR really buffer HR? Test of a moderated model. International Journal of Economic Research, 14(20), 1-18.

Abdullah, N., Noh, M. N., Mansor, R., Hashim, M. A. T., \& Teck, W. K. (2015). Penilaian pelaksanaan pentaksiran berasaskan sekolah (PBS) dalam kalangan guru sains. Jurnal Pendidikan Sains \& Matematik Malaysia. Vol. 5, No. 1, 89-102.

Acar-Erdol, T., \& Yildizli, H. (2018). Classroom assessment practices of teachers in Turkey. International Journal of Instruction. Vol. 11, No. 3, 587-602.

Ali, M. A. M., \& Jamaluddin, S. (2007). Amalan pentaksiran untuk pembelajaran di sekolah menengah. Jurnal Pendidikan, 27(1), 19-39.

Black, P., \& Wiliam, D. (2009). Developing the theory of formative assessment. Educational Assessment, Evaluation and Accountability, 21, 5-31.

Bramwell-Lalor, S., \& Rainford, M. (2016). Advanced level biology teachers' attitudes towards assessment and their engagement in assessment for learning. European Journal of Science and Mathematics Education. Vol. 4, No. 3, 380-396.

Cauley, K. M., \& McMillan, J. H. (2010). Formative assessment techniques to support student motivation and achievement. Clearing House, 83(1), 1-6.

Gamlem, S. M., \& Smith, K. (2013, August 16). Student perceptions of classroom feedback. Assessment in Principles, Policy and Practice, 20, 150-169. Retrieved from doi:10.1080/0969594X.2012.749212.

Henry, J. (2002, June 5). Forget the marking, start talking. Retrieved from http://www.tes.co.uk/article.aspx?storycode=366141.

Lebar, O. (2012). Pengkajian Kualitatif: Pengenalan kepada Teori dan Metod. Ed. ke 4. Tanjung Malim: Universiti Pendidikan Sultan Idris. 
Malaysian Examination Board. (2013, May 26). Sistem pentaksiran ke arah pembangunan modal insan kelas pertama. Retrieved from http://buletinkpm.blogsport.com/2013/04/sistempentaksiran-ke-arah-pembangunan.html.

McMillan, J. H. (2014). Classroom assessment: Principles and practice for effective standardsbased instruction. 6th ed. Boston: Pearson.

McNergney, R. F., \& McNergney, J. M. (2007). Foundations of education: The challenge of professional practice. 4th ed. Boston: Allyn \& Bacon.

Merriam, S. B. (2009). Qualitative research: A guide to design and implementation. San Francisco: Jossey-Bass.

Miles, M. B., \& Huberman, A. M. (2015). Qualitative data analysis: An expanded sourcebook. 2nd ed. Thousand Oaks, CA: Sage Publications.

Ministry of Education Malaysia. (2018). Panduan pelaksanaan pentaksiran bilik darjah. Putrajaya: Bahagian Pembangunan Kurikulum.

Maskan, N. (2013). Pelaksanaan pentaksiran berasaskan sekolah (PBS) bagi mata pelajaran sains di sekolah kebangsaan daerah Pontian, Johor. Tesis Sarjana UTHM. Tidak diterbitkan.

Nicol, D., \& Macfarlane-Dick, D. (2006). Formative assessment and self-regulated learning: a model and seven principles of good practice. Studies in Higher Education, 31(2), 199-218.

Nizam, M. F., Hamzah, G. M. S., Nidzam, C., Adnan, M. \& Noh, N. M. (2014). Pembinaan instrumen amalan pentaksiran guru matematik sekolah menengah. Jurnal Pendidikan Sains \& Matematik Malaysia. Vol 4, No. 1 Jun 2014. 1-14.

Patton, M. Q. (2014). Qualitative Research \& Evaluation Methods. 4th ed. Beverly Hills. Sage Publications, Inc.

Payne, D. A. (2003). Applied educational assessment. Toronto: Wadsworth.

Popham, W. J. (2013). Classroom Assessment: What Teachers Need To Know. Boston: Pearson Education, Inc.

Ravikumar, K. V. (2015). Amalan pentaksiran dalam PdP Kurikulum Standard Sekolah Rendah di Sekolah Kluster. Jurnal Pendidikan Dedikasi. Jilid 9, 1-17.

Reeves, D. B. (2001). Standards make a difference: The influence of standards in classroom assessment. NASSP Bulletin, 85(5), 5-12.

Shute, V. J. (2008). Focus on formative feedback. Review of Educational Research, 78(2), 153-189.

Stiggins, R. J. (2010). Conquering the formative assessment frontier. dlm. McMillan, J. H. (Ed.). Formative classroom assessment. New York: Teachers College Columbia University. 8-28.

Stiggins, R. J., Arter, J. A., Chappius, J., \& Chappius, S. (2007). Classroom assessment for student learning: Doing it right-using it well. New Jersey: Pearson Education, Inc.

Suah, S. L., Ong, S. L., \& Osman, S. (2007). Pentaksiran pembelajaran pelajar: Amalan guruguru di Malaysia. Malaysian Education Dean's Council Journal, 5, 68-83.

Sulaiman, S., Norhaziah, M. S., Mohamad, I., Amily, M. S., Noriza, N., \& Razana B. (2016). The development of the pedagogical content knowledge (PCK) Standard for Malaysian ICT Teachers. Journal of ICT in Education,1, 29-41.

Wilson, M. (2010). Assessment for Learning and for Accountability. Paper presented at the Exploratory Seminar: Measurement Challenges Within the Race to the Top Agenda Center for K-12 Assessment \& Performance Management. Retrieved from http://www. k12center. org/publications.html. 
Vol. 8, No. 3, 2019, E-ISSN: 2226-6348 C 2019 HRMARS

Yin, R. K. (2017). Case study research and applications: Design and methods. 6th ed. United Kingdom: Sage Publication, Inc.

\section{Acknowledgement}

I would like to express my sincere appreciation to my supervisor Associate Professor Dr. Asri Selamat. I am very grateful for his advice and support throughout this article. His frank and honest word of wisdom motivate me to do better throughout the process of completing this article.

Other than that, I would like to express million thanks to headmistress Pn. Hjh. Safiah Sarif and her teachers assist in conducting interviews. The cooperation shown by these school teachers made it easy for me to complete this assignment.

\section{Corresponding Author}

Senin Bin Khamis,

Profesionalism Practices Unit,

IPG Kampus Perempuan Melayu, 75400 Melaka, Malaysia

E-mail: senin@ipgkpm.edu.my 